\title{
Polonca Zupančič
}

\section{Heraklova blaznost pri Evripidu}

\section{SIMPTOMI IN OPISI BLAZNOSTI}

Čeprav na pojav blaznosti naletimo $\mathrm{v}$ različnih zvrsteh grške literature, se opisi vendarle ne razlikujejo povsem - Bennett tako ugotavlja, da so se sčasoma oblikovali trije ustaljeni vzorci oziroma modeli opisov, t. i. poetični, filozofski in medicinski model. Za poetični model, ki ga zastopajo Homer in tragiki, naj bi bilo značilno, da nenormalna duševna stanja vselej povzroča neka zunanja sila, navadno božanstvo; pri tem lahko te sile vodi nek jasen motiv, kot je maščevanje, ali pa ravnajo zgolj na podlagi trenutnih vzgibov in kapric. Ker pa vzrok blaznosti prihaja od zunaj, tudi ozdravitev nastopi $s$ posredovanjem božanstva ali človeka. Ta model so zagovorniki drugih dveh modelov zavrnili kot primitivnega in praznovernega, saj temelji na veri $\mathrm{v}$ obstoj nadnaravnih sil, ki lahko vplivajo na človeka in uravnavajo njegovo življenje. V okviru filozofskega modela so tako duševna stanja opredeljena kot posledice delovanja notranjih sil v človeku; predstavnik Platon npr. trdi, da blaznost nastopi, ker nižji predeli duše nadvladajo racionalne, ozdravitev pa nastopi, ko se znova vzpostavi pravilno razmerje med posameznimi silami. Po medicinskem modelu so mentalna stanja bistveno odvisna od delovanja organov, navadno srca ali možganov. Nenormalna stanja se po tej razlagi pojavijo, ker se organi preveč navlažijo, s tem pa se naravno ravnotežje znotraj njih poruši. S spremenjenim načinom življenja, pravilno dieto ter zdravili naj bi bilo mogoče to ravnovesje ponovno vzpostaviti in tako odpraviti tako fizične kot duševne nepravilnosti. ${ }^{1}$

Ti trije modeli so seveda shematični in ne izključujejo medsebojnih povezav; tako npr. Collingev svojem prispevku raziskuje, vkolikšni meri različni literarni pisci, med drugim tudi Evripid, v svojih delih uporabljajo medicinske izraze, ki jih sicer zasledimo v sočasnih »znanstvenih « besedilih. Ugotavlja,

1 Bennett, »Mind and Madness«. 
da je besedišče pri Evripidu nekakšna mešanica tehničnih in netehničnih izrazov, golega in metaforičnega govora, kar kaže na to, da je bil seznanjen s sočasnim medicinskim žargonom, aktualnimi znanstvenimi tematikami in obravnavanimi boleznimi. Tudi njegovi opisi blaznosti v precejšnji meri sledijo konvencionalnim predstavam o duševni nestabilnosti, kot se pojavljajo $\mathrm{v}$ medicinski literaturi - omenjajo se namreč običajni simptomi, kot so zavijanje z očmi, slinjenje, nasilnost in izguba zavesti. ${ }^{2}$ Povezavi med medicinskimi spisi in Evripidovimi dramami se posveča tudi Ferrinijeva, ki na podlagi svoje analize potrjuje trditev, da je Evripid zelo dobro poznal sočasna besedila tega žanra. V svoja dela je namreč vpletal tipične simptome epilepsije, kot so opisani v hipokratskih spisih: ti se pojavijo nenadoma, brez jasnega razloga, prav tako hitro pa tudi minejo; manifestirajo se kot pena na ustih, spremembe $\mathrm{v}$ očeh, škripanje z zobmi, nehoteni gibi, vidne ali slušne halucinacije, strah in tesnoba, oteženo dihanje, dezorientacija in izguba spomina, po koncu napada pa sta razvidna šibkost in občutek sramu. ${ }^{3}$

Kot bomo videli v nadaljevanju, se omenjeni simptomi pojavljajo prav $\mathrm{v}$ tragediji Heraklova blaznost. ${ }^{4} \mathrm{Na}$ prve opise prihajajoče blaznosti lahko naletimo že $\mathrm{v}$ pogovoru med obema boginjama, ki sta prišli po Herinem naročilu - o simptomih presenetljivo spregovori prav Lisa, personificirana blaznost v podobi ženske boginje: ${ }^{5}$ omenja nekontrolirano tresenje $\mathrm{z}$ glavo, zavijanje $\mathrm{z}$ očmi, motne krvave oči, izgubo glasu ter nepravilno dihanje, ki mu sledi divje rjovenje. Takole pravi:

$\tau \varepsilon \dot{\varepsilon} \kappa v^{\prime}$ àं



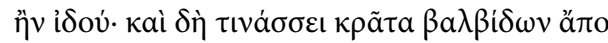

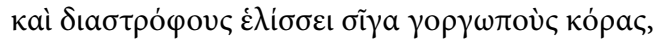

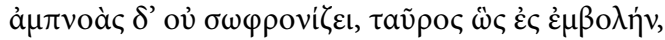

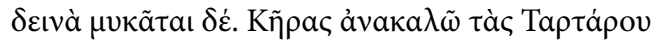

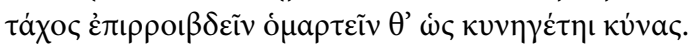

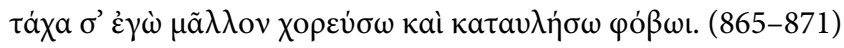

2 Collinge, »Medical Terms and Clinical Attitudes «, 45 in 48.

3 Ferrini, »Tragedia e patologia«, 51-52. Za obširnejši pregled medicinske terminologije v tragediji glej tudi Miller, »Medical Terminology in Tragedy«.

4 Ko se Herakles po podvigu v Hadu vrne v Tebe k svoji družini, ugotovi, da je v tem času Evbojčan Likos prevzel oblast in jih kljub prošnjam obsodil na smrt. Herakles se mu za to nemudoma maščuje in ga ubije, toda veselje družine je le kratkotrajno, kajti Hera, Heraklova stara sovražnica, pošlje nadenj glasnico bogov Iris in Liso, boginjo blaznosti oziroma njeno personifikacijo, da bi ga spravili v stanje norosti. V deliriju Herakles pobije svojo ženo in otroke, ki jih je še ravnokar rešil, uboj očeta Amfitriona pa prepreči Atena. Ta namreč vanj vrže skalo in povzroči, da Herakles pade v globok spanec. Ko se naposled prebudi in ugotovi, kaj je storil, si že hoče vzeti življenje, a ga od tega odvrne njegov prijatelj, atenski kralj Tezej, ki mu v Atenah ponudi nov dom.

5 Blaznost so Grki povezovali z ženskimi lastnostmi, $s$ htonskim, $\mathrm{z}$ nenadzorovanim divjanjem in besnenjem, ki je rušilno in uničevalno, zato so jo navadno upodabljali zelo podobno kot Erinije - kot žensko s pasjimi oziroma kačjimi potezami, tako fizičnimi (zlasti na vaznih upodobitvah je Lisa prikazana s pasjo glavo) kakor značajskimi. Zelo pogosto je imela tudi krila. Prim. Padel, "Blood in the Mind«, 163; »Whom Gods Destroy«, 17-18. 
Najprej pomorim otroke: on pa se ne bo zavedel, da mori sinove lastne, dokler moj urok ne mine.

Glej ga: že srdito suče glavo, tek se že pričenja,

že $z$ očmi molče zavija, moten je pogled gorgonski,

glej, že sunkovito diha, kakor bik tik pred napadom,

strašno rjove, da odmeva Tártar, kliče črne Kere,

naj ga spremljajo z blaznečim krikom kakor lovski psi.

Kmalu boš še bolj zaplesal ob piščali pesmi grozni. (Prevod Brane Senegačnik.)

Vidik, ki ga Theodoru ne izpostavi posebej, ga pa poudarjajo drugi interpreti, ${ }^{6}$ je prizor lova oziroma pregona nasploh: $v$ tem prizoru namreč boginje podzemlja nastopijo kakor božanske preganjalke, ki so Heraklu stalno za petami in mu ne omogočijo počitka. Ta podoba je pomembna zaradi nadaljevanja zgodbe, ko se vloge preganjalca in preganjanega zamenjajo in Herakles postane tisti, pred komer beži njegova družina. Po drugi strani je pomenljiva tudi simbolika živali, s katerimi drugi liki na več mestih primerjajo Herakla in na ta način izpostavljajo njegovo divjost. Kot se izrazi Padelova, blaznost ogroža meje med človeškim in živalskim ter jih ukinja. ${ }^{7}$ Ker Lisa in Erinije utelešajo nečloveško moč, se tudi njihove žrtve v napadih blaznosti spremenijo v nečloveška, divja, živalska bitja. Tudi Baudy izpostavlja povezavo Likosa in Lise: imena obeh namreč koreninita v besedi za volka, $s$ tem pa prevzemata tudi njegove značilnosti. ${ }^{8}$ Ko Herakles ubije Likosa, stopi na njegovo mesto in prevzame njegovo vlogo - $\mathrm{z}$ vstopom Lise $\mathrm{v}$ njegovo telo namreč postane podoben divji zveri, volku, kot takšen pa dokonča, kar je nameraval storiti že Likos - ubiti njegovo družino. Smrt družine po tej razlagi potemtakem $\mathrm{z}$ nujnostjo sledi smrti Likosa. ${ }^{9}$

Herakles je dalje predstavljen kot podivjan pes, ki se pripravlja na lov (934), primerjava z bikom (869-870), ki sicer izpostavlja tudi njegovo moč, pa prav tako poudarja divjo naravo in neracionalno nasilje. ${ }^{10}$ Podobe podivjanih psov, konj oziroma kočij, ki zaidejo s tirnic, ter vsakršno priganjanje in šibanje (npr. 863, 880-882, 947-949) so prispodoba neke zunanje sile, pa tudi moči, blaznosti, divjosti in nereda, ki presega vse meje in vodi v katastrofo, ki zahteva posredovanje božanstva. Atenin prihod ima brez dvoma ključno vlogo pri nadaljnjem razvoju dogodkov, saj Heraklu prepreči očetomor, njena naglica in uporaba sile pa kažeta na urgentno situacijo in težavnost naloge. ${ }^{11}$

$\mathrm{V}$ Lisinem govoru je močno prisotna tudi glasba, ki spremlja preobrat Herakla v poblaznelega divjaka, piščal pa aludira na slovesnosti v čast bogu

6 Papadopoulou, Heracles and Euripidean Tragedy; Provenza, "Madness and Bestialization«, 68.

7 Padel, Whom Gods destroy, 143. Prim. tudi Neils Boulter, »The Theme of Agria«, 105.

8 Baudy, »Die Herrschaft des Wolfes«, 160.

9 Ibid., 169.

10 Bik je povezan tudi z Dionizom, Zevsom in Hero, njenim kultom in žrtvovanjem - Evripid je na ta način povezal mitologijo s simbolizmom. Več o tem v Provenza, »Madness and Bestialization," 87-91.

11 Papadopoulou, Heracles and Euripidean tragedy, 126. 
Dionizu, ki je bil povezan $\mathrm{z}$ nenavadnimi stanji. Kot se izrazi Provenza, je Heraklova »manija predstavljena kot degeneracija dionizičnega navdahnjenja. « ${ }^{12}$ Vsi ključni preobrati so namreč pospremljeni z glasbo in plesom, katerih analizi se Provenza v svojem delu precej posveča; zlasti je ključnega pomena Lisin govor, $\mathrm{v}$ katerem pravi, da ga bo ob zvoku piščali pognala $\mathrm{v}$ nebrzdan divji ples (871), ki se bo naposled končal s pobojem (877-879). Tudi Padelova nekaj pozornosti nameni analizi glasbe in plesa $\mathrm{v}$ povezavi z blaznostjo; med napadom se namreč telo zvija, kar ustvarja videz neharmoničnega, neurejenega plesa, to pa še toliko bolj poudarja kontrast med redom in neredom, prav in narobe, prisebnostjo in blaznostjo. ${ }^{13}$

Po Lisinem opisu grozot Herakles zares zblazni, a tega Evripid zaradi pesniških konvencij ni prikazal na odru. ${ }^{14} \mathrm{Pač}$ pa po napadu nastopi sel, ki na prošnjo zbora opiše dogajanje $\mathrm{v}$ hiši, pri tem pa že omenjenim simptomom nenormalnega duševnega stanja (tišina, zavijanje $z$ očmi, krvave oči) prida še dva nova: slinjenje in divji smeh.

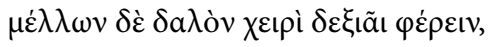

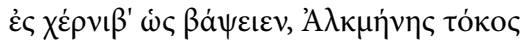

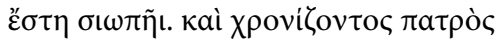

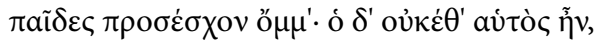

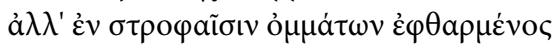

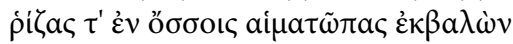

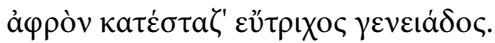 \\ है $\lambda \varepsilon \xi \varepsilon \delta^{\prime} \ddot{\alpha} \mu \alpha \gamma \dot{\varepsilon} \lambda \omega \tau \iota ~ \pi \alpha \rho \alpha \pi \varepsilon \pi \lambda \eta \gamma \mu \varepsilon \dot{v} \nu \omega \iota$ [...] (928-935) \\ Ko baklo prime, da bi jo ugasnil \\ v obredni vodi, je Alkmenin sin \\ molče obstal. Otroci vanj zazro se, \\ a on že nič več ni bil isti: zenice \\ nemirno se mu sučejo, v očeh \\ izstopijo krvave žilice \\ in pena $\mathrm{z}$ goste brade mu kaplja. \\ Kot blaznež se zasmeje [...] (Prevod Brane Senegačnik.)
}

Zlasti pretirano izločanje sline in zavijanje $\mathrm{z}$ očmi, ki se omenjata na tem mestu, sta bila tradicionalna in splošna simptoma neobičajnih duševnih stanj, zato ni nenavadno, da ju je Evripid uporabil za vzbujanje večjega vtisa prepričljivosti. ${ }^{15} \mathrm{~V}$ nadaljevanju glasnik opisuje stanje popolnega delirija,

\footnotetext{
12 Provenza, »Madness and Bestialization «, 72.

13 Padel, Whom Gods destroy, 132.

14 Glej tudi Beta, "Madness on the Comic Stage«. Beta v svojem članku na podlagi primerjave Evripidove tragedije in Aristofanovih Os izpeljuje tezo, da sta obstajali dve verziji Heraklove blaznosti - v zgodnji naj bi bil poboj družine dejansko prikazan na odru, v drugi verziji pa ga je potem Evripid v skladu s konvencijo umaknil.

15 Theodoru, "Subject to Emotion«, 34. Glej tudi Uvod.
} 
v katerem Herakles halucinira, da jezdi v Megaro, kjer se najprej okrepča, v Istmu se spopade $\mathrm{z}$ namišljenim nasprotnikom, nato pa misli, da $\mathrm{v}$ Mikenah pobija Evristejeve otroke, a v resnici kolje lastne. Herakles torej med napadom videva stvari, ki jih drugi ne, oziroma zamenjuje osebe okrog sebe za nekoga drugega; večina komentatorjev se strinja, da je pri Heraklu njegova zabloda prej $\mathrm{v}$ napačni zaznavi, saj zamenjuje dejansko obstoječe osebe in reči z drugimi. ${ }^{16}$ Pri tem O'Brien opozori na zanimivo dejstvo, da o halucinacijah pri Heraklu izvemo šele iz poročila sla, medtem ko med simptomi, ki jih napoveduje Lisa, niso omenjene. Šele naknadno torej izvemo, da je bil Herakles med napadom blaznosti v veliki meri podvržen prividom, in to celo izredno kompleksnim. ${ }^{17}$

Prizor poboja se naposled zaključi z Ateno, ki mu v glavo vrže veliko skalo, služabniki in oče Amfitrion, ki je edini ubežal smrti, pa ga trdno privežejo k stebru. Padelova izpostavlja prav omembo kamenja in povezave kamenjanja z blaznostjo: ta je vselej nekaj, kaj je družbi tuje, zunanje, saj se nahaja onkraj družbenih norm in pričakovanih vzorcev obnašanja. Skupnost si zato prizadeva, da bi takšno osebo potisnila karseda daleč od sebe, najbolj konkretno obliko izgona pa naj bi predstavljajo prav kamenjanje - element, na katerem temelji civilizacija, naj bi simbolno in fizično ločil pripadnika te civilizacije in tujca, blazneža in človeka pri zdravi pameti. ${ }^{18}$

Ko se Herakles naposled prebudi, njegovo dihanje še ni pomirjeno, ves je zmeden in se ne spominja ničesar:

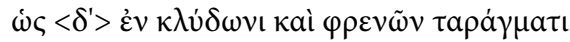

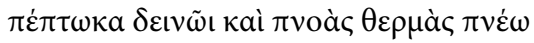

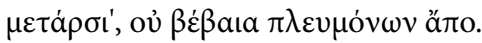

[...]

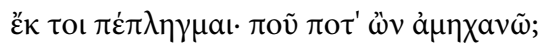

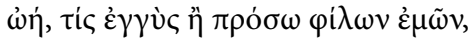

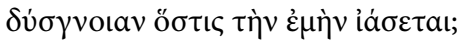

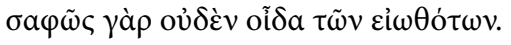

(1091-1093 in 1105-1108)

$\mathrm{O}$, kakšen val viharni mi duha

je zmedel! Plitev še in vroč moj dih je,

in niso se mi pljuča še umirila.

[...]

Kako sem zmeden! O nemoč! O kje sem?

Ohej, prijatelji, kjerkoli ste!

Kdo te nevednosti me bo ozdravil?

Vse tuje je, ničesar ne spoznam. (Prevod Brane Senegačnik.)

16 Ibid. 44; Aguirre, »Erinyes as the Creatures of Darkness «, 134; Conacher, »The Orestes«, 217; Said, "From Homeric ate to tragic Madness«, 391; O’Brien Moore, "Madness in Ancient Literature«, 117-118; Gärtner, "Der mythische Held in saekularisierter Umgebung«, 4.

17 O’Brien Moore, »Madness in Ancient Literature « , 127-128.

18 Padel, Whom Gods destroy, 100-101. 
Pri Heraklu se pojavljajo nekateri značilni simptomi blaznosti, ki so po hipokratskih spisih klasični simptomi epilepsije. Theodoru v svojem prispevku poudarja, da je blaznost opisana predvsem fizično in izpostavlja osem različnih fizioloških simptomov, ki so znanilci oziroma pokazatelji nenormalnega duševnega stanja: molčanje $(867,930)$, metanje glave vznak (866), zavijanje z očmi $(867,932,990)$, težko, nepravilno, sunkovito dihanje (868), krvave oči oziroma moten pogled $(867,933)$, slinjenje (934), oglašanje z živalskimi glasovi (869) in divji smeh (935). ${ }^{19}$

Napad je dalje postavljen v središče pozornosti in je ključnega pomena za razvoj dogodkov, saj vodi do tragičnega preobrata, ki bo Herakla zaznamoval do konca življenja. Čeprav nam je na voljo le posredni opis dejanskega dogajanja (o njem izvemo iz komentarja Lise in Amfitriona oziroma sla), je Evripid pri tem uporabil različne perspektive in napad opisal tako $z$ vidika povzročiteljice še pred samim dogodkom kakor $z$ vidika prič, ki so lahko na lastne oči spremljale dogajanje. Lisa tako izredno natančno opiše potek napada, pri tem pa deloma govori o prihodnjem dogajanju kot o dogodku, do katerega bo nedvomno prišlo, deloma pa za dosego večjega dramatičnega učinka uporabi sedanjik. Amfitrionov komentar sledi neposredno po napadu in je oblikovan kot dialog z zborom; sam je bil priča dogodkom, o katerih sedaj pripoveduje, hkrati pa je v dogajanje tudi močno čustveno vpleten, zato na podlagi njegovih besed ni povsem jasno, kaj se pravzaprav dogaja. Jasnejši in bolj detajliran opis nudi šele glasnik, ki dokončno potrdi Amfitrionovo zgodbo. Herakles kot zadnji interpretira in ovrednoti dogodke s svoje perspektive: ko naposled dojame, kaj je storil, se svojega ravnanja sramuje in ga obžaluje. ${ }^{20}$

\section{INTERPRETACIJA BLAZNOSTI IN VPRAŠANJE KRIVDE}

Interpretacije tragedije se močno razlikujejo med sabo, zato jih je težko predstaviti shematično. Kljub temu so nekateri komentatorji poskušali določiti kriterije, na podlagi katerih bi lahko sistematizirali obstoječe interpretacije Heraklove blaznosti. Shirley Barlow tako komentatorje glede na to, $\mathrm{v}$ čem prepoznavajo enotnost drame, deli $\mathrm{v}$ dve skupini: $\mathrm{v}$ prvo prišteva tiste, ki so kontinuiteto in razvoj videli $\mathrm{v}$ samem junaku oziroma $\mathrm{v}$ njegovi etični drži, medtem ko so interpreti druge skupine iskali ponavljajoče se teme oziroma jezikovne vzorce - zlasti so poudarjali motiv prijateljstva in moči ali pa podobe, kot so lok ali podoba Gorgone. ${ }^{21}$ Tudi Papadopolou loči med dvema skupinama interpretov. V prvo spadajo tisti, ki so poskušali najti kako Heraklovo karakterno napako in na podlagi tega upravičevati pojav blaznosti,

19 Theodoru, »Exploring Madness«, 34 .

20 Papadopoulou, Heracles and Euripidean Tragedy, 60-61.

21 Barlow, »Structure and Dramatic Realism«, 115. 
medtem ko so drugi poudarjali njegovo idealizirano podobo, ki je žrtev božanske maščevalnosti. ${ }^{22} \mathrm{~V}$ slednjem primeru se torej oblikuje nasprotje med interpreti, ki so zagovarjali poseg neke zunanje sile, in tistimi, ki so izhajali iz delovanja notranjih, duševnih sil, s tem pa krivdo za uboj pripisovali Heraklu.

\section{Heraklova blaznost kot zunanja sila}

Predstavnica prve skupine je na primer Rileyjeva, za katero je blaznost neka drugost, neka tujost oziroma, kot se izrazi sama, zunanje in arbitrarno vsiljevanje tujosti - povzročena je od zunaj, od bogov. ${ }^{23}$ Lisa tako deluje znotraj Herakla, vendar po njenem mnenju ni podaljšek oziroma manifestacija njegove psihološke strukture, ravno nasprotno: Herakles je tisti, ki manifestira njeno neustavljivo silo in Herino nepomirljivo jezo, s tem pa sta prikazana simbolna izguba in preoblikovanje njegovega jaza. ${ }^{24}$ Vstop Lise $\mathrm{v}$ hišo sovpade $\mathrm{z}$ njenim vstopom v Herakla, uničenje hiše pa ponazarja Heraklov propad. Podobno misel je oblikoval tudi Grube, ki je sočasne psihoanalitične razlage označil za neprepričljive in bil mnenja, da je vzrok Heraklove blaznosti povsem zunaj njega, to pa naj bi ponazarjal prav nenaden prihod boginj. ${ }^{25}$ Da v Heraklu pred prihodom boginje Lise ni nobenega znamenja, ki bi nakazovalo blaznost, trdi tudi Head: dalje pravi, da v Heraklu tudi ni nobenih karakternih lastnosti, ki bi jih Lisa lahko izkoristila in na njih zasnovala Heraklov izpad. Po njegovem mnenju je njegova blaznost nečloveška, zato nujno prihaja $\mathrm{z}$ neba. ${ }^{26}$ Theodoru je dalje eden izmed redkih komentatorjev, ki je primerjal lik Herakla z likom blaznega Oresta in postavil tezo o dveh različnih podobah blaznosti: Heraklova blaznost je po njegovem povzročena od zunaj in se zato manifestira zlasti s fizičnimi simptomi, medtem ko je pri Orestu blaznost opisana kot bolezensko stanje oziroma kot bistveni del njegove osebnosti, simptomi pa so precej bolj psihosomatski. $^{27}$

Po mnenju večine, če ne kar vseh tistih navedenih interpretov, ki priznavajo neko zunanjo silo, je Herakles prikazan kot nedolžen. ${ }^{28} \mathrm{Na}$ to naj bi napeljevali že uvodni prizori, ki postavljajo uzurpatorja Likosa v kontrast s Heraklom in poudarjajo njegove pozitivne odlike - Chalk kontrast opredeli s konceptoma

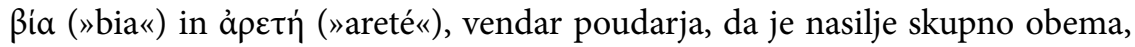
čeprav po drugi strani v Heraklovih dejanjih ni zaznati nobene űßpıৎ (»hybris«),

\footnotetext{
22 Papadopoulou, »Herakles and Hercules«, 259.

23 Riley, The Reception and Performance, 14. Prim. tudi Papadopoulou, Heracles and Euripidean Tragedy, 61 in 70.

24 Riley, Reasoning Madness, 14.

25 Grube, The Drama of Euripides, 252-256. Povzeto po Riley, Reasoning Madness, 207-216. Prim. tudi Papadopoulou, Heracles and Euripidean Tragedy, 8o-84.

26 Head, "Hercules «, 4.

27 Theodoru, »Exploring Madness«, 34-35.

28 Npr. Kamerbeek, »Unity and Meaning«, 9; Chalk, »Areth and Bia«, 15.
} 
ki bi bila vzrok blaznosti. ${ }^{29}$ Herakles od trenutka, ko se pojavi na odru, daje vtis racionalnosti in premišljenosti, $v$ njegovem govoru in obnašanju pa naj ne bi bilo moč zaznati nobenega pokazatelja duševnega neravnovesja. ${ }^{30}$

Povsem nepričakovana je epifanija boginj na odru, saj so se bogovi tradicionalno pojavili bodisi na začetku bodisi na koncu tragedij, še bolj pomenljiva pa je odsotnost Zevsa, saj je navsezadnje Heraklov oče. Evripid naj bi Heraklovo nedolžnost izrazil tudi s tem, ko celo sama boginja blaznosti Lisa, poosebljena iracionalnost, ugovarja Herinemu naročilu in ga ne izvrši brez obotavljanja, pri tem pa izkaže veliko mero sočutja in racionalnosti (843863). S tem ko se Lisi to dejanje upira, je toliko bolj poudarjena neracionalnost maščevanja, ki je ključna za oblikovanje kontrasta med nepravično Hero in nedolžnim Heraklom. Toda v trenutku, ko sprejme nalogo, se zopet poistoveti s svojim prejšnjim bistvom. Tudi sama epifanija obeh boginj na odru, ki nima paralele v ohranjenih grških tragedijah, in to na sredini poteka drame, je veliko več kot zgolj scenski efekt, saj se priprava na pojav blaznosti odvija neposredno pred očmi gledalca in kaže, da junakova blaznost ne izrašča iz njega samega; želje po uboju Evristeja in njegovih otrok ne čuti že od vsega začetka, pač pa je rezultat Herine zamere. Pri tem se sklicujejo tudi na Tezeja, ki krivdo za blaznost pripisuje bogovom $(1189,1234,1315)$. Dalje je pomenljivo dejstvo, da se blaznost izraža preko junakove vrline - v tem primeru preko fizične moči, ki je zaradi delovanja božanstva potencirana do te stopnje, da se Herakles ne more več obvladati; tragika je v tem, da Herakles svoje otroke in ženo pobije prav z lokom, s pomočjo katerega je pred tem izvršil toliko svojih slavnih del. Parodijo njegovih junaštev vidi Rileyjeva tudi v njegovih halucinacijah: $\mathrm{v}$ iluziji potovanja, gostitve, rokoborbe in poboja na koncu. In nenazadnje, ko se Herakles naposled zave svojega dejanja, ga obžaluje in sprejme odgovornost zanj ter tako pusti vtis ljubečega očeta. ${ }^{31}$ Čeprav med samim pobojem ni bil priseben, se zaveda, da je kljub temu odgovoren za dejanje. ${ }^{32}$

\section{Heraklova blaznost kot patološka naravnanost}

Pomemben premik v interpretaciji Heraklove blaznosti označuje nastop t. i. dunajskega modernizma in oblikovanje psihologije kot nove znanosti. Filologi so namreč uporabili dognanja v psihologiji v svojih delih in pričeli obravnavati tragiške prikaze kot klinične primere. Tako je na primer Wilamowitz v svoji interpretaciji postavil trditev, da so zametki blaznosti v Heraklu prisotni še pred prihodom Herinih poslank, in tako »razkril« junakovo patološko

29 "Arethe and Bia«, 15-16.

30 Riley, Reasoning Madness, 24-28; Brooke Holmes, "Euripides' Heracles in the Flesh«, 253; Kamerbeek, »Unity and Meaning«, 12.

31 Riley, Reasoning Madness, 37. Prim. tudi Brooke Holmes, The Symptom and the Subject, 244, in "Euripides' Heracles in the Flesh «, 260; Griffiths, "Euripides' Herakles«, 647.

32 Hartigan, »Euripidean Madness«, 126-129. Prim. tudi Riley, Reasoning Madness, 29-34. 
naravnanost $\mathrm{k}$ maščevanju in pobijanju. Povnanjenje te blaznosti predstavlja le vrh že dlje časa trajajoče motnje, ki se razvija postopoma - Herakla naj bi po njegovi razlagi zaznamovala leta pobijanja, tako da je njegova želja po krvi prestopila meje normalnosti. Dokaz mentalne nestabilnosti in bližajočega se izbruha blaznosti naj bi bil Heraklov govor o maščevanju (62-82), ki je po eni strani izraz herojske jeze, po drugi pa manije. ${ }^{33}$

Verrall je oblikoval podobno tezo: Herakles naj bi bil blazen že od prihoda dalje, pojav boginj pa je razložil z racionalističnega vidika kot sanjski privid zbora, ki nato prikladno pozabi na dogodke - Lisa in Iris se namreč prikažeta le zboru, glavni junaki o njiju ne vedo ničesar, pa tudi zbor ju kasneje ne omenja več. ${ }^{34}$ Njegovo teorijo je kasneje ponovil Norwood, ki je trdil, da Herakles trpi za naraščajočo nagnjenostjo $\mathrm{k}$ poblaznelim izpadom, duševna nestabilnost pa je bila tisto, kar ga je naposled pripeljalo do poboja svoje družine. ${ }^{35}$ Tudi Murray je v svoji interpretaciji sledil Wilamowitzu; po njegovi razlagi je Herakles sicer dobrosrčen in strasten junak, ki ga pokoplje ravno lastna moč - njegove lastnosti se namreč v novih pogojih razvijejo v eksces, blaznost je posledica njegove megalomanije. ${ }^{36}$ Dodds je Heraklovo blaznost označil kot manično depresijo, Herakla pa za junaka, ki očitno ponazarja nadvlado iracionalnega nad razumom, ${ }^{37}$ Blaiklock za epileptični napad (na epilepsijo kažejo prividi, zvijanje telesa, glasen jok, plitvo dihanje, izguba spomina, težko dihanje ter šibkost po napadu) ${ }^{38}$ Kamerbeek pa je umore v racionalistični luči razlagal kot nasilna dejanja preobremenjenega človeka. ${ }^{39}$

\section{Heraklova blaznost kot posledica njegovega mejnega statusa}

Naslednja skupina komentatorjev je izhajala iz Heraklove dvojne narave in $\mathrm{v}$ tem videla razlog za pojav blaznosti. Tako je Silk v svojem delu izpostavil zlasti edinstveno Heraklovo naravo polboga, ki se od drugih herojev razlikuje po svoji brutalnosti in nenasitnih apetitih. Je marginalna, prehodna figura, prav zaradi tega pa tudi nestabilna, vselej na meji med človekom in bogovi ter tako grožnja obojim. ${ }^{40}$ Iris in Lisa o njem govorita kot o človeku (npr. 825, $835,846,849$ ), zbor pa ga ima enkrat za žrtev bogov, drugič pa za božansko silo. Do konca drame je Herakles prikazan kot človek, pa tudi sam se ima za nasprotnika bogovom, proti katerim so ljudje nemočni $(1243,1253)$.

33 von Wilamowitz, Euripides: Herakles, 128-131.

34 Verrall, Essays on Four Plays of Euripides, 168-174.

35 Norwood, Greek Tragedy, 232.

36 Murray, Greek Studies, 112.

37 Dodds, »Euripides the Irrationalist«, 100.

38 Blaiklock, »The Epileptic«, 48-63. Tudi v antičnih zdravstvenih delih je Heraklovo stanje opisano kot epilepsija oziroma "sveta bolezen«, kakor so jo poimenovali takrat. Zaradi Heraklove zgodbe se je zanjo uveljavil izraz »Heraklova bolezen«.

39 Kamerbeek, »Unity and Meaning«.

40 Silk, "Heracles and Greek Tragedy«, 6. Prim. tudi Papadimitropoulos, "Heracles as Tragic Hero«, 131 in 134. 
Mejni status Herakla in iz tega izvirajočo grožnjo zanj in njegovo družino izpostavlja tudi Papadimitropoulos, a namesto dveh govori o treh dimenzijah: božanski, človeški in živalski, ki jo predstavlja prav Heraklova podzavest. Papadimitropoulos je mnenja, da so destruktivne sile v Heraklu tako notranje kot zunanje, blaznost pa je tako le eden izmed aspektov Heraklovega karakterja - Lisa naj bi delovala na nezavedni ravni. Da sta Lisa in Herakles pravzaprav zlita eden v drugega, naj bi kazale primerjave obeh z Gorgono $(868,999)$, bakhantkami $(898,1119,1122)$ in uporaba kočije $(760,880) .{ }^{41}$ Tudi Papadopolou meni, da je Evripid kontrast med Likosom in Heraklom ustvaril zgolj z namenom, da bi ga kasneje izničil in pomešal vrlino in pretiravanje, pozitivno in negativno plat Heraklovega herojstva. Tako v njegovi prisebnosti kakor v blaznosti je izrazito poudarjena njegova nasilnost, zato postane njegovo upravičevanje maščevanja problematično. Dvojna narava njegove moči ga lahko po eni strani povzdigne na raven boga, po drugi pa vrže na raven živali. Pokazatelj asimilacije dobrega in slabega je njegova grožnja, da bo sovražnikom odsekal njihove glave (870), kar ga postavlja na raven divjaka oziroma na mejo med človekom in živaljo. Hkrati je Herkul stalno tudi na meji med človekom in božanstvom, kar ga umešča v še toliko bolj nestabilen položaj. ${ }^{42}$

\section{Druge interpretacije}

Kosakova gre v svoji interpretaciji v povsem svojo smer s tezo, da Heraklova bolezen izvira iz okužbe, okolja in bogov. Pri tem vzporeja politično situacijo v Tebah s Heraklovo boleznijo in pravi, da se zunanje neurejeno stanje v državi materializira kot notranja nestabilnost, ki se kaže kot blaznost: način, kako ta politična situacija vpliva na njegovo družino, je ekvivalenten temu, kako se bolezen, ki zajema celotno mesto, odraža na Heraklovem telesu. Mestu se namreč dogaja razpad na posamezne entitete brez prave osrednje oblasti, to pa ogroža Heraklovo družino. Kaos, ki zaznamuje Tebe, z Likosovim umorom izgine in se v nadaljevanju preko božanskega posredovanja prenese na Heraklovo telo in duševnost, s tem pa nastopi tudi okužba - tako blaznost kot okužba ga izolirata od družbe, a iz različnih razlogov. Medtem ko blaznost bolnika odreže iz okolja, ker okolja ne zaznava več kot ostali, pa je okužba v tej vlogi zaradi svoje narave - je namreč nalezljiva. ${ }^{43}$

Shirley Barlow v nasprotju s Kosakovo ne vidi nobene očitne povezave med umorom Likosa in pojavom blaznosti; prepričana pa je, da dogodki sledijo eden drugemu $\mathrm{z}$ namenom, da bi bil kontrast med tremi stopnjami nasilja (junaškimi deli, ubojem Likosa in ubojem družine) čim večji. Posebno pozornost nameni prvi zborovski pesmi in poročilu sla, ki ju je Evripid umestil

41 »Heracles as Tragic Hero«, 134-136.

42 Papadopoulou, »Herakles and Hercules«, 262-266.

43 Clarke Kosak, Heroic Measures, 151-152 in 169-17o. 
prav pred nastopom pomembnih dogodkov, Heraklovo vrnitvijo in prizorom rehabilitacijo. V prvi zborski pesmi ni moralnega razmisleka ali emocialnih izjav, prav tako namenoma ni omembe fizičnega napora, strahu, bolečine ali grozot; pri tem so junaška dela reducirana zgolj na dekorativni element. Poročilo sla je temu nasprotno, saj je v njem veliko aktivnosti, gibanja, sprememb, pa tudi jezik postane epsko vzvišen. Umor Likosa služi kot prehod med obema drugima deloma. ${ }^{44}$

Omembe vredna je tudi Griffithsova interpretacija, po kateri so figure otrok pomemben namig za razumevanje pomena tragedije: medtem ko ne vidi nobene povezave med ubojem Likosa in otrok, pa označi poboj otrok za ironijo, saj naj bi se Evripid poigraval z idejo prihoda in odhoda v Had - svoje otroke bo Herakles poslal tja, od koder je sam ravnokar prišel (838). ${ }^{45}$ Poleg tega naj bi povezavo med troglavim Kerberjem in otroci nakazovala tudi Evripidova inovacija, da ima Herakles tri otroke, medtem ko jih je v drugih verzijah več. Pri tem ima prav Heraklovo poslednje junaško delo, ko je pripeljal Kerberja iz podzemlja, za tisto dejanje, ki je Heri dalo razlog za preganjanje Herakla, saj je z vstopom v Had prestopil mejo med ljudmi in bogovi ter porušil kozmični red. ${ }^{46}$ Herakles je namreč s tem segel onkraj tiste poti, ki smrtnikom omogoča dosego nesmrtnosti, torej seksualne reprodukcije, problem pa je po Griffithsu nastal, ker naravni in nenaravni način doseganja nesmrtnosti ne moreta hkrati obstajati v eni osebi.

\section{KONEC DRAME}

Kot opozarja Rileyjeva, je razumevanje konca v drami Heraklova blaznost odvisno predvsem od tega, kako interpretiramo junakovo zavrnitev samomora - se ponovno prebudi njegov »stari« heroizem ali pa se nastopi neka nova vrsta herojstva? Sama se nagiba k drugi razlagi: po njenem mnenju se drama zaključi z rehabilizacijo Herakla kot junaka in njegovo humanizacijo, pri tem pa se vrednote »starega « herojstva, ki sta jih utelešala lok in sulice, zamenjajo z vrednoto prijateljstva. Še pred svojim padcem je bil Herakles prikazan kot netipičen sofisticiran junak, ki je poudarjal vrednost pravega prijateljstva konec drame tako ne prikazuje preloma s Heraklovim prejšnjim jazom, pač pa postopni razvoj oziroma dozorevanje tega jaza, ki se prej kot na fizično opira na duševno moč. Na to kaže njegova odločitev, da bo orožje obdržal, čeprav (in ker) ga bosta vselej spominjala na njegovo poslednje delo. ${ }^{47}$ Kamerbeek v nasprotju z Rileyjevo trdi, da ta njegova odločitev implicira, da Herakles ne zavrača svojih prejšnjih junaških del in vendarle ostaja isti človek kakor

\footnotetext{
44 Barlow, "Structure and Dramatic Realism", 116, 188-124.

45 Griffiths, »Euripides' Herakles«, 641-652.

46 Prim. Chalk, »Arethe and Bia«, 13; Papadimitropoulos, »Heracles as Tragic Hero«, 131, 134.

47 Riley, Reasoning Madness, 40.
} 
prej. ${ }^{48}$ Papadopoulou njegovo odločitev razlaga v luči dvojnosti: kakor lahko lok uporablja za dobro in slabo, tako ga bo spominjal prav na ambivalentnost njegovega herojstva. Ta odločitev poudarja njegovo emocialno in mentalno moč. Na ta način je Evripid povabil občinstvo k razmisleku o nestabilni naravi moči in o lastnih omejitvah. ${ }^{49}$ Tudi Chalk je naklonjen teoriji Heraklovega razvoja, saj pravi, da Heraklova ả $\varepsilon \imath \tau \dot{~(» a r e t e ́ «) ~ v ~ z a d n j e m ~ d e l u ~ v k l j u c ̌ u j e ~}$ veliko več kot "areté« prvega dela, razlikujeta pa se, ker se oblikujeta v različnih okoliščinah. ${ }^{50}$ Po njegovem mnenju je Evripid lik Likosa (ki je bil dejansko njegova iznajdba) vpeljal le zato, da bi ta predstavljal vidik surove sile, poboj otrok pa sledi junaškim delom $\mathrm{z}$ namenom, da izrazi neizogiben padec vrline, ki jo potem prijateljstvo vodi dalje. ${ }^{51}$

Silk nasprotuje tezi o kontinuiranem razvoju med prejšnjim in sedanjim Heraklom; pravi, da obstaja kvečjemu metafizična kontinuiteta med Heraklom in božanskim kraljestvom, ki mu pripada tudi pojav blaznosti. Zaradi svojega vmesnega položaja je bil Herakles grožnja božanskemu svetu, blaznost pa je po njegovem mnenju po eni strani predstavljena kot arbitrarna odločitev bogov, v metafizičnem smislu pa nastopi kot nujnost - na ta način namreč Herakles, ki je na začetku človek-bog, postane popolni človek, s tem pa je odstranjena vsakršna poprejšnja grožnja svetu bogov. ${ }^{52}$

\section{ZAKLJUČEK}

Kot je bilo prikazano v prispevku, se interpretacije vzrokov za Heraklov napad blaznosti precej raznolike; zasledimo lahko tako razlage, ki vidijo vzroke za blaznost v delovanju nekih zunanjih, božanskih oziroma nadnaravnih silah, kakor tudi psihoanalitične in racionalistične interpretacije, ki iščejo pojasnila $\mathrm{v}$ junakovi psihi in patološki naravnanosti. Nadrobnejši pretres argumentov je pokazal, da so v Heraklovem primeru precej bolj prepričljivi avtorji, ki pojav blaznosti pojasnjujejo z njegovim mejnim statusom, ki se mora izčistiti, da bi se kozmično ravnovesje lahko zopet vzpostavilo - razlog za nastop blaznosti tu potemtakem izhaja iz nečesa, na kar Herakles pravzaprav sploh ne more vplivati; kot polbog se je namreč že rodil. V prid tej razlagi govori nastop samih boginj na odru in Lisin govor, v katerem se predstavi kot zunanja sila, ki bo delovala znotraj Heraklovega telesa, po uboju pa odšla iz njega. Prav tako je dejstvo, da se poboj družine zgodi med samim napadom.

S tem je povezano tudi vprašanje krivde, ki do neke mere ostaja nerešeno: znotraj obeh tragedij je namreč mogoče zaznati nihanje med prevzemanjem

48 Kamerbeek, »Unity and Meaning «, 7.

49 Papadopoulou, »Herakles and Hercules«, 267.

50 Chalk, "Arethe and Bia«, 12.

51 Ibid., 18.

52 Silk, »Heracles and Greek Tragedy«, 17-18. Podobno tudi Riley, Reasoning Madness, 43-45. 
odgovornosti in prelaganjem krivde na zunanjo silo. Herakles vendarle (vsaj na videz) iskreno obžaluje in poskuša storjeno krivico izravnati s samomorom. Ob branju drame se zares zdi, da nam Evripid ne daje nobenega razloga, da bi podvomili v pristnost Heraklovih čustev in poboj lastne družine razumeli kot izraz notranjega sovraštva; tudi v primeru, če njegovo blaznost razumemo kot povnanjenje njegove (prave) patološke narave, ne moremo trditi, da ga žene sovraštvo oziroma kakršno koli negativno čustvo do družine. Večina interpretov zato Heraklovo zgodbo jemlje zelo resno, njegovo blaznost pa označuje za tragično.

Če pojav blaznosti vidimo kot razkol znotraj junakove psihe, lahko zares rečemo, da je pri Heraklu prevladala njegova virtus. Po drugi strani pa Evripid vendarle ni podal nedvoumnega odgovora na vprašanje, kaj pravzaprav vodi posameznika pri njegovem delovanju - gre res za nadnaravne sile, ki lahko posegajo $\mathrm{v}$ človekovo življenje in nanj vplivajo, ali pa je človek popolnoma svoboden in takšne razlage prikladno uporabi za upravičevanje svojih dejanj ter si tako zatiska oči pred svojo pravo naravo?

\section{BIBLIOGRAFIJA}

\section{Kritične izdaje in prevodi}

Kovacs, David, izd. Suppliant women; Electra; Heracles. Cambridge: Harvard University Press, 1998.

Murray, Gilbert, izd. Euripidis fabulae 2. Oxford: Clarendon Press, 1937.

Murray, Gilbert, izd. Euripidis fabulae 3. Oxford: Clarendon Press, 1969.

Senegačnik, Brane, prevod. Evripid. Heraklova blaznost. Ljubljana: Družina, 2000.

Wilamowitz-Moellendorf, Ulrich von, izd. Griechische Tragoedien. Bd. 1. Berlin: Weidmann, 1904.

Wilamowitz, Ulrich von, izd. Euripides: Herakles. 2 zvezka. Berlin: Weidmann, 1895.

\section{Druga literatura}

Aguirre, Mercedes. »Erinyes as the Creatures of Darkness. « V: Light and Darkness in Ancient Greek Myth and Religion, ur. Menelaos Christopoulos, Efimia Karakantza in Olga Levaniouk, 133-41. United Kingdom: Lexington Books, 2010.

Barlow, Shirley A. »Structure and Dramatic Realism in Euripides 'Heracles'." GeR 29.2 (1982): 115-25.

Baudy, Gerhard J. »Die Herrschaft des Wolfes: Das Thema der 'verkehrten Welt' in Euripides' Herakles. «Hermes 121.2 (1993): 159-80.

Bennett, Simon. »Mind and Madness in Classical Antiquity." V: History of Psychiatry and Medical Psychology, 175-97. Harvard University: Springer US, 2008.

Beta, Simone. »Madness on the Comic Stage: Aristophanes' Wasps and Euripides' Heracles.« GRBS 40 (1999): 135-57.

Blaiklock, E. M. »The Epileptic. « GəR 14.41-42 (1945): 48-63.

Chalk, H. H. O. »Arethe and Bia in Euripides' Herakles.« JHS 82 (1962): 7-18. 
Clarke Kosak, Jennifer. Heroic Measures: Hippocratic Medicine in the Making of Euripidean Tragedy. Ur. John Scarborough, Philip Van der Eijk, Ann Hanson in Nancy Siraisi. Studies in Ancient Medicine 30. Boston: Brill, 2004.

Collinge, N. E. »Medical Terms and Clinical Attitudes in the Tragedians.« BICS 9.1 (1962): 43-55.

Conacher, D. J. »The Orestes.« V: Euripidean drama: myth, theme and structure, 213-24. Toronto: University of Toronto Press, 1967.

Dodds, E. R. »Euripides the Irrationalist.« CR 43.3 (1929): 97-104.

Ferrini, Fernanda. »Tragedia e patologia: Lessico ippocratico in Euripide.« QUCC 29 (1978): 49-62.

Gärtner, Thomas. »Der mythische Held in saekularisierter Umgebung: zum Orestes des Euripides.« Prometheus 31 (2005): 1-28.

Griffiths, E. M. »Euripides' Herakles and the Pursuit of Immortality.» Mnemosyne 55.6 (2002): 641-56.

Grube, G. M. A. The Drama of Euripides. London: Methuen, 1941.

Hartigan, Karelisa. »Euripidean Madness: Herakles and Orestes.« Ge 34.2 (1987): 126-35.

Head, James. »Hercules: the Spiritual Emphasis in Euripides. "The Spectrum: A Scholars Day Journal 1.1 (2011): 1-6.

Holmes, Brooke. »Euripides' Heracles in the Flesh.« CA 27.2 (2008): 231-81.

. The Symptom and the Subject: the Emergence of the Physical Body in Ancient Greece. New Jersey: Princeton University Press, 2010.

Kamerbeek, J. C. »Unity and Meaning of Euripides’ Heracles.« Mnemosyne 19.1 (1966): $1-16$.

Miller, Harold W. »Medical Terminology in Tragedy.« TAPA 75 (1944): 156-67.

Murray, Gilbert. Greek Studies. Oxford: University Press, 1946.

Neils Boulter, Patricia. »The Theme of Agria in Euripides' Orestes'» Phoenix 16.2 (1962): 102-106.

Norwood, Gilbert. Greek Tragedy. London: Methuen, 1920.

O'Brien Moore, Ainsworth. »Madness in Ancient Literature.« Doktorska disertacija. Princeton University 1924.

Padel, Ruth. »Blood in the Mind." V: In and out of the Mind: Greek Images of the tragic Self, 162-92. Princeton: Princeton University Press, 1992.

. Whom Gods destroy: Elements of Greek and Tragic Madness. New Jersey: Princeton University Press, 1995.

Papadimitropoulos, Loukas. »Heracles as Tragic Hero.« CW 101.2 (2008): 131-38.

Papadopoulou, Thalia. Heracles and Euripidean tragedy. Cambridge: Cambridge University Press, 2005.

. "Herakles and Hercules: The Hero's Ambivalence in Euripides and Seneca." Mnemosyne 57.3 (2004): 257-83.

Provenza, Antonietta. »Madness and Bestialization in Euripides’ Heracles.« CQ 63.1 (2013): 68-93.

Riley, Kathleen. The Reception and Performance of Euripides' Herakles: Reasoning Madness. Oxford: Oxford University Press, 2008.

Said, Suzanne. »From Homeric ate to tragic Madness. « V: Mental Disorders in the Classical World, ur. William Harris, 363-94. Leiden: Brill, 2013.

Silk, M. S. »Heracles and Greek Tragedy.« GઐR 32.1 (1985): 1-22.

Theodoru, Zena. »Subject to Emotion: Exploring Madness in Orestes. « The Classical Quarterly 43,št. 1 (1993): 32-46.

Verrall, A. W. Essays on Four Plays of Euripides: Andromache, Helen, Heracles, Orestes. Cambridge: Cambridge University Press, 1905. 